\title{
Analisis Penguasaan Konsep dan Kesulitan Siswa pada Materi Teori Kinetik Gas
}

\author{
Mimi Rohazal Yaumi ${ }^{1}$, Sutopo ${ }^{1}$, Siti Zulaikah ${ }^{1}$ \\ ${ }^{1}$ Pendidikan Fisika-Universitas Negeri Malang
}

\begin{tabular}{l} 
INFO ARTIKEL \\
\hline Riwayat Artikel: \\
Diterima: 09-05-2019 \\
Disetujui: 17-10-2019 \\
\hline
\end{tabular}

\section{Kata kunci:}

conceptual understanding, kinetic theory of gasses; student difficulties; penguasaan konsep; teori kinetik gas;

kesulitan siswa

\begin{abstract}
ABSTRAK
Abstract: The purpose of this study was to analysed conceptual understanding and difficulties (misconceptions) of students in the kinetic theory of gases. Test consisted of 9 reasoned multiple choice questions administered after students study the material. From the results of the study, students get an average score of 7.1 from maximum score of 9. Students have mastered the concept of the relationship between ideal gas state quantities (pressure, volume, temperature) and kinetic energy of ideal gases. However, students still have difficulty in determining internal energy if the number of particles changing, the average speed of ideal gases, and the application of ideal gas law to the circulatory phenomena in the heart.
\end{abstract}

\begin{abstract}
Abstrak: Penelitian ini bertujuan untuk menganalisis penguasaan konsep dan kesulitan (miskonsepsi) siswa pada materi teori kinetik gas. Soal tes terdiri dari sembilan soal pilihan ganda beralasan yang diberikan setelah siswa mempelajari materi tersebut. Dari hasil penelitian, siswa mendapatkan skor rata-rata 7,1 dari skor maksimal 9. Siswa telah menguasai konsep hubungan antar besaran keadaan gas ideal (tekanan, volume, suhu) dan energi kinetic gas ideal. Namun, siswa masih mengalami kesulitan dalam menentukan energi internal dengan jumlah partikel gas yang berubah, kelajuan rata-rata gas ideal, dan aplikasi persamaan keadaan gas pada fenomena peredaran darah di jantung.
\end{abstract}

\author{
Alamat Korespondensi: \\ Mimi Rohazal Yaumi \\ Pendidikan Fisika \\ Universitas Negeri Malang \\ Jalan Semarang 5 Malang \\ E-mail: mimiryaumi@gmail.com
}

Penguasaan konsep merupakan salah satu indikator keberhasilan pembelajaran fisika. Penguasaan konsep merupakan kemampuan dalam memahami fakta yang ada di sekitar dan membandingkan dengan konsep secara ilmiah. Penguasaan konsep yang baik dapat menjelaskan keteraturan fenomena alam yang ada di sekitar (Docktor \& Mestre, 2014). Selain itu, penguasaan konsep yang baik dapat menunjang dalam penyelesaian masalah fisika (Sands, 2014). Oleh sebab itu, penelitian tentang penguasaan konsep rutin dilakukan dalam beberapa dekade terakhir (Duit, 2009). Penelitian tentang penguasaan konsep menjabarkan tentang pola pikir subjek dalam memahami konsep dan kesulitan-kesulitan umum atau miskonsepsi (Bouwma, Gearhart, Stewart, \& Brown, 2009).

Miskonsepsi merupakan konsep yang berbeda dengan hasil penelitian ilmiah (Kele \& Özsoy, 2009). Miskonsepsi yang terjadi menunjukkan rendahnya penguasaan konsep. Penelitian membuktikan miskonsepsi banyak terjadi di berbagai topik fisika atau sains (Alwan, 2011; Chang et al., 2007). Topik-topik yang banyak diteliti dan ditemukan miskonsepsi diantaranya hukum Newton(Jayanti, Wartono, Sutopo, 2016; Sari, Parno, Taufiq, 2018), listrik dinamis (Turgut, Gürbüz, \& Turgut, 2011), gerak harmonis (Husnaini \& Chen, 2019), suhu kalor (Alwan, 2011) dan termodinamika (Meltzer, 2004). Miskonsepsi ini akan mengganggu pembelajaran selanjutnya. Miskonsepsi yang ada dalam diri siswa akan sulit ditangani jika tidak dipertegas dengan strategi pembelajaran yang tepat (Docktor \& Mestre, 2014).

Penelitian tentang penguasaan konsep pada materi teori kinetik gas lebih banyak dilakukan pada mahasiswa. Konsep yang dibidik dalam materi ini terkait sifat gas ideal, persamaan keadaan gas dan hukum-hukum yang melatarbelakanginya, energi gas ideal, dan kelajuan rata-rata gas ideal. Penelitian pada mahasiswa umumnya hanya dilakukan pada topik tertentu seperti hubungan antar variabel keadaan (tekanan, volume, suhu) atau persamaan keadaan gas (Aydeniz, Pabuccu, Cetin, \& Kaya, 2012; Bouwma,Gearhart et al., 2009; Robertson \& Shaffer, 2013, 2016). Hasil penelitian menunjukkan adanya miskonsepsi pada mahasiswa. Mahasiswa sulit menerapkan persamaan keadaan gas dengan variabel keadaan gas (tekanan, suhu, volume) yang berubah-ubah (Monteyne, Gonzalez, \& Loverude, 2008). 
Miskonsepsi lain menunjukkan bahwa mahasiswa menganggap massa sama dengan volume gas (Robertson \& Shaffer, 2013). Mahasiswa juga sulit dalam menghubungkan besaran makroskopis (tekanan, volume, suhu) terhadap besaran mikroskopis gas ideal, seperti kelajuan, frekuensi tumbukan, energi kinetik (Robertson \& Shaffer, 2016). Hal ini pun menguatkan bahwa mahasiswa dapat menggunakan persamaan keadaan gas namun tidak dapat mengaitkan dalam proses-proses dalam fenomena di sekitar (Russ, Coffey, Hammer, \& Hutchison, 2009).

Materi tentang teori kinetic gas telah dipelajari di jenjang sebelumnya yaitu SMA. Namun, pada kenyataannya masih banyak miskonsepsi pada mahasiswa. Selain itu, penelitian tentang penguasaan konsep teori kinetik gas pada siswa SMA masih jarang dilakukan. Oleh karena itu, penelitian ini membidik cara subjek (siswa) dalam menguasai konsep teori kinetik gas dan kesulitan yang dialami siswa. Hasil penelitian pada artikel ini dapat digunakan sebagai rujukan dalam mengembangkan pembelajaran yang cocok pada materi teori kinetik gas pada siswa SMA.

\section{METODE}

Penelitian deskriptif ini dilakukan di tiga kelas XI MIPA pada salah satu SMA Negeri di Kota Batu. Subjek penelitian terdiri dari 85 siswa. Data penguasaan konsep siswa diambil dengan memberikan tes tulis. Tes diberikan setelah siswa mempelajari materi teori kinetik gas. Soal tes terdiri dari sembilan soal pilihan ganda beralasan dengan reliabilitas 0,7 . Soal tes memiliki daya beda antara 0,2 hingga 1,2 dengan rata-rata 0,74, tingkat kesukaran antara 0,2 hingga 0,9 dengan rata-rata 0,7, dan korelasi dengan skor total antara 0,4 hingga 0,9 dengan rata-rata 0,6. Konstruksi penguasaan konsep yang diujikan dapat dilihat pada tabel 1. Data dianalisis dengan cara menentukan presentase pada jawaban yang benar siswa. Penguasaan siswa dikatakan baik jika presentase jawaban benar lebih dari 50\% (Sari, Parno, \& Taufiq, 2018). Alasan jawaban yang ditulis siswa dianalisis dengan cara konstan komparatif yaitu memberikan label (kode) pada alasan jawaban siswa yang secara substantif (Glaser \& Strauss, 2009). Alasan siswa yang salah menunjukkan adanya kesulitan atau kurangnya penguasaan konsep pada siswa.

Tabel 1. Indikator Pencapaian Kompetensi Soal Tes Penguasaan Konsep Teori Kinetik Gas

\begin{tabular}{lll}
\hline \multicolumn{1}{c}{ Tema } & \multicolumn{1}{c}{ Indikator Pencapaian Kompetensi } & Nomor Soal \\
\hline Persamaan & Menyebutkan persyaratan keadaan gas ideal & 1 \\
Keadaan Gas & Menganalisis gerak partikel gas berdasarkan besaran keadaannya & 2 \\
Ideal & Menghitung suhu gas ideal berdasarkan grafik $P V$ pada proses volume & \\
& tetap & \\
& Menentukan tekanan pada serambi jantung ketika mengalami relaksasi & \\
& (mengembang) & \\
& Menentukan volume gas ideal dengan menggunakan persamaan gas ideal \\
& pada proses tekanan tetap \\
& Mengidentifikasi besaran makroskopis (tekanan, suhu, atau volume) pada \\
& proses tidak familiar (tekanan, suhu, dan volume) berubah) berdasarkan \\
& grafik PV & \\
\hline Energi Kinetik, & Menentukan energi kinetik rata-rata gas berdasarkan suhu berdasarkan \\
Energi Internal, & informasi grafik $P V$ \\
dan Kelajuan & Menghubungkan suhu dan jumlah partikel gas terhadap besar energi \\
Rata-Rata Gas & internal gas \\
Ideal & Menentukan kelajuan rata-rata (rms) partikel gas berdasarkan keadaan \\
& suhunya \\
\hline
\end{tabular}

\section{HASIL}

Soal tes untuk menguji penguasaan konsep siswa pada materi teori kinetik gas berupa pilihan ganda beralasan. Dari hasil penelitian didapatkan sebanyak $81,4 \%$ siswa berhasil menjawab benar pada soal-soal penguasaan konsep teori kinetik gas dengan skor rata-rata 7,1 dari skor maksimal 9. Persentase jawaban benar pada masing-masing soal dapat dilihat pada gambar 1.

\section{Persamaan Keadaan Gas Ideal}

Soal terkait persamaan keadaan gas terdapat pada nomor 1 hingga 6. Soal ini terkait hubungan antar variabel keadaan secara makroskopis dari gas ideal yaitu tekanan, volume, dan suhu yang dituliskan:

$$
P V \propto T
$$

Hubungan antar tekanan, volume, dan suhu ini merupakan gabungan dari percobaan Robert Boyle, Jacques Charles, dan Joseph Gay-Lussac (Cummings, Halliday, \& Activity Based Physics Group, 2004). Hasil percobaan ketiganya kemudian Boyle Gay-Lussac. Kemudian dengan menambahkan konstanta yang sebanding dengan jumlah partikelnya, maka persamaan keadaan gas dapat dituliskan 
Persamaan tersebut juga setara dengan

$$
\begin{aligned}
& P V=N k T \\
& P V=n R T
\end{aligned}
$$

Soal nomor 1 siswa memilih pernyataan agar persyaratan persamaan keadaan gas ideal dapat berlaku (ciri-ciri gas ideal) seperti pada gambar 2 .

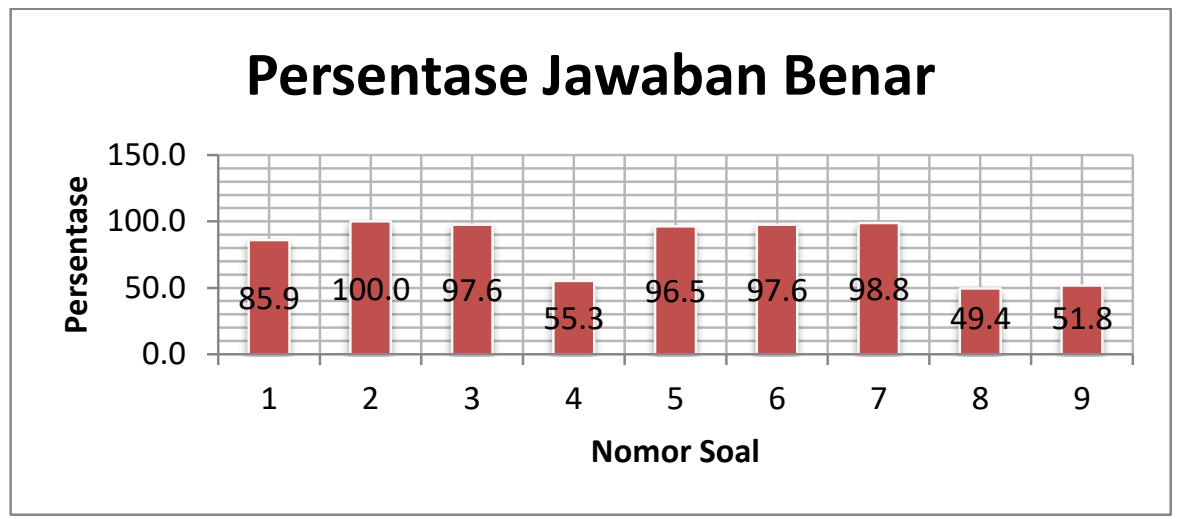

Gambar 1. Persentase Jawaban Benar

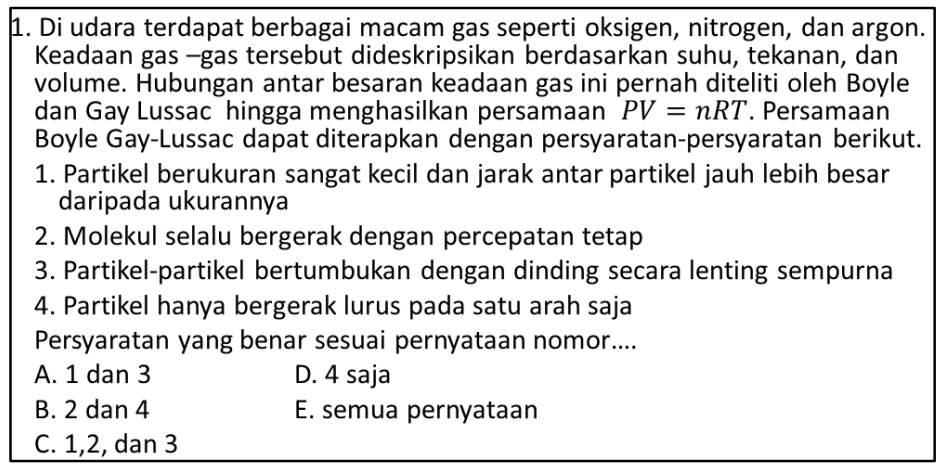

Gambar 2. Butir Soal No. 1

Pada soal ini $85,9 \%$ siswa dapat menyebutkan dengan benar persyaratan persamaan keadaan gas ideal dapat berlaku. Siswa dapat menyebutkan bahwa gas ideal terdiri dari partikel yang sangat kecil dengan jarak partikel sangat besar apabila dibandingkan dengan ukurannya. Partikel gas bergerak ke segala arah (tidak satu arah saja) dengan kelajuan tetap dan menumbuk dengan dinding secara lenting sempurna. Namun, pada soal ini, beberapa siswa masih terjebak dengan pilihan pernyataan yang menyebutkan bahwa partikel ags idealbergerak dengan percepatan tetap, bukan kecepatan tetap. Soal nomor 2 siswa menganalisis gerak partikel gas melalui gambar yang mengilustrasikan piston yang ditarik ke atas seperti pada gambar 3.

\footnotetext{
2. Sejumlah partikel gas berada pada tabung piston yang salah satu ujungnya dapat bergerak bebas seperti pada gambar di samping. Jika piston ditarik ke atas pada proses suhu tetap tetap, perubahan yang terjadi adalah....

A. partikel semakin sering menumbuk dinding

B. partikel semakin jarang menumbuk dinding

C. energi kinetic rata-rata partikel gas bertambah besar

D. energi kinetik rata-rata partikel gas berkurang

E. partikel bergerak dengan kelajuan yang semakin besar
}

Gambar 3. Butir Soal No. 2 
Pada soal ini, seluruh siswa berhasil menganalisis gerak partikel gas setelah piston ditarik ke atas pada suhu tetap. Partikel gas akan semakin jarang menumbuk dinding ketika volume wadah gas membesar. Siswa memberikan alasan semakin besar volume, semakin besar juga ruang untuk bergerak sehingga jarang menumbuk baik dengan dinding maupun dengan sesame partikel. Selain itu, ada beberapa siswa yang mengaitkan dengan definisi partikel secara mikroskopis. Tekanan pada gas ideal bergantung pada sering tidaknya partikel menumbuk dinding. Volume dan tekanan bebanding terbalik $\left(P \sim \frac{1}{V}\right)$ sehingga semakin besar volume, samakin kecil tekanan dan partikel jarang menumbuk dinding. Ada pula yang mengaitkan bahwa semakin besar volume, semakin kecil tekanan sehingga gaya partikel ke dinding semakin kecil karena gaya dan tekanan sebanding $(F \sim P)$.

Soal nomor 3 hingga 6 membahas tentang hubungan antar variabel keadaan gas ideal. Hubungan antar variabel keadaan ini terkait hubungan tekanan dan suhu pada proses volume tetap, hubungan tekanan dan volume pada suhu tetap, hubungan volume dan suhu pada tekanan tetap. Selain ketiganya, terdapat soal hubungan antara volume, suhu, dan tekanan pada proses ketiganya yang berubah-ubah (proses tidak familiar). Butir soal dapat dilihat pada Gambar 4(a), (b), (c), dan (d).

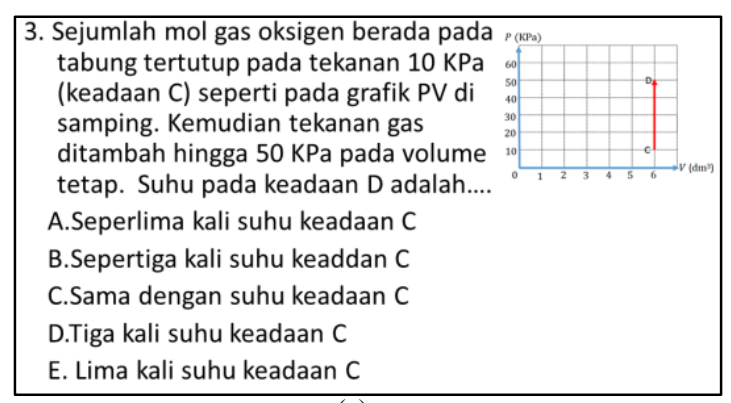

(a)

\begin{tabular}{|l|}
\hline 5. Dua wadah di laboratorium digunakan untuk \\
mengukur volume bersdasarkan besaran \\
keadaannya. Kedua wadah berisi jumlah \\
partikel gas yang sama. Kedua wadah dalam \\
keadaan tekanan yang konstan. Wadah dua (2) \\
berada pada suhu ruang $\left(27^{\circ} \mathrm{C}\right)$ dan wadah satu \\
(1) berada pada suhu $127^{\circ} \mathrm{C}$. Volume pada \\
wadah satu (1) adalah.... \\
A. $4 / 3$ kali volume wadah 2 \\
B. $3 / 2$ kali volume wadah 2 \\
C. $5 / 3$ kali volume wadah 2 \\
D. $5 / 2$ kali volume wadah 2 \\
E. $8 / 3$ kali volume wadah 2 \\
\hline
\end{tabular}

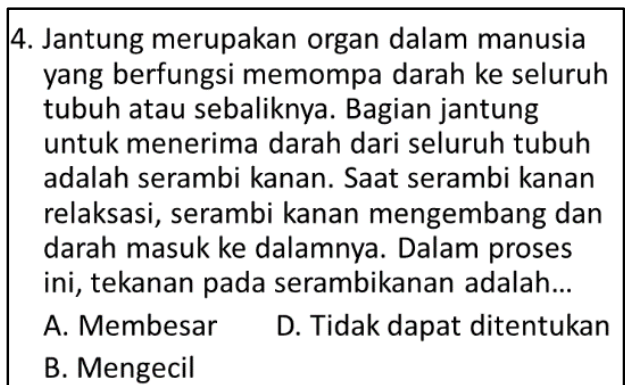

B. Mengecil

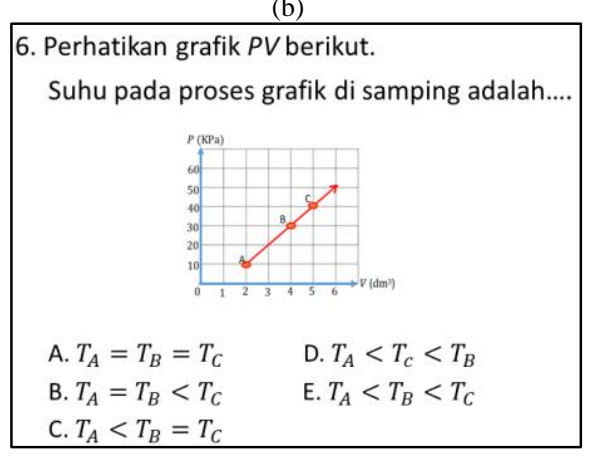

Gambar 4 (a). Butir Soal No. 3 (b) Butir Soal No.4 (c) Butir Soal No. 5 (d) Butir Soal No. 6

Sebagian besar siswa $(97,6 \%)$ dapat menjelaskan hubungan tekanan dan suhu pada volume tetap menggunakan grafik $P V$ seperti soal pada Gambar 4(a). Siswa menunjukkan bahwa tekanan dan suhu berbanding lurus $(P \sim T)$. Siswa memberikan alasan dengan perhitungan menggunakan persamaan keadaan gas ideal bahwa $T=\frac{P V}{n R}$. Siswa menentukan suhu pada maisngmaisng ke adaan (C dan D) kemudian membandingkannya. Selain menggunakan rumusan tersebut, siswa juga menggunakan kesebandingan yaitu $\frac{P_{C}}{P_{D}}=\frac{T_{C}}{T_{D}}, \frac{P_{C}}{T_{C}}=\frac{P_{D}}{T_{D}}$, atau $\frac{T_{C}}{T_{D}}=\frac{P_{C} V_{C}}{P_{D} V_{D}}$. Dari cara tersebut, siswa mengetahui bahwa suhu di keadaan D5 kali suhu keadaan C. Namun, ada siswa yang memberikan alasan bahwa suhu sebanding dengan volume $(T \sim V)$ sehingga suhu di kedua keadaan adalah sama. Hal ini menunjukkan adanya miskonsepsi pada siswa tersebut.

Pemahaman siswa mengenai hubungan antara tekanan dan volume dianalisis melalui soal tentang kerja serambi kanan (jantung) seperti soal pada gambar 4(b). Siswa yang menjawab benar (55,3\%) menyatakan bahwa saat serambi kanan mengembang (volume bertambah), maka tekanan dalam serambi kanan akan mengecil karena tekanan dan volume berbanding terbalik $\left(P \sim \frac{1}{V}\right)$. Ada siswa yang menyatakan bahwa tekanan dalam serambi kanan mengecil agar darah bisa masuk ke dalamnya. Ada pula siswa yang menjawab benar tekanan mengecil karena serambi kiri memompa darah ke serambi kanan sehingga darah dapat masuk. Alasan ini merupakan jawaban yang salah karena darah yang masuk ke dalam serambi kanan merupakan darah dari seluruh tubuh bukan dari serambi kiri. Namun, sebanyak 44,7\% siswa menjawab salah menyatakan bahwa saat paru-paru mengembang, maka tekanan juga besar. Tekanan yang besar ini juga dikarenakan darah memenuhi serambi kanan. Selain itu, ada siswa yang salah mengartikan bahwa darah mengalir dari serambi kanan ke luar sehingga tekanan dalam bilik kanan besar. Hal ini dikarenakan darah akan mengalir dari tekanan timggi ke rendah. 
Pemahaman siswa mengenai hubungan volume dan suhu pada proses tekanan tetap dianalisis melalui soal pada Gambar 4(c). Sebanyak 96,5\% siswa menjawab benar. Siswa menyatakan bahwa volume sebanding dengan tekanan $(V \sim T)$. Siswa menggunakan rumusan kesebandingan $\frac{V_{A}}{V_{B}}=\frac{T_{A}}{P_{A}}: \frac{T_{B}}{P_{B}}$ atau $\frac{V_{A}}{V_{B}}=\frac{T_{A}}{T_{B}}$. Siswa yang memberikan jawaban salah menunjukkan kesalahannya pada perhitungan matematika.

Pemahaman siswa pada hubungan antar ketiga variabel keadaan dilihat dari soal pada gambar 4 (d). Sebanyak 97,6\% siswa menajwab benar. Siswa beralasan bahwa grafik semakin naik sehingga suhu akan semakin besar dan suhu sebanding pada tekanan dan volume gas. Siswa menentukan suhu pada masing-maisng keadaan menggunakan persamaan keadaan gas yaitu $T=\frac{P V}{n R}$ atau $T=P V$. Dengan menentukan suhu maisng-maisng keadaan kemudian diurutkan dari yang terkecil hingga terbesar. Sementara itu, siswa yang menjawab salah tidak memberikan alasan apapun.

\section{Energi Kinetik, Energi Internal, dan Kelajuan Rata-Rata Gas Ideal}

Soal terkait energi kinetic, energi internal, dan kelajuan rata-rata gas ideal terdapat pada soal 7—9. Maisng-maisng soal menanyakan tentang energi kinetic, energi internal, kamudian kelajuan rata-rata gas ideal. Pada ketiga soal ini, ada dua soal yang memiliki persentase rendah pada jawaban benar. Butir soal 7—9 dapat dilihat pada gambar 5 (a), (b), dan (c).

\begin{tabular}{|l}
\hline 7. Perhatikan grafik $P V$ berikut ini. \\
Perbandingan energi kinetik rata-rata pada \\
keadaan C dan D adalah... \\
\begin{tabular}{ll} 
A. $2: 5$ & D. $5: 2$ \\
B. $3: 4$ & E. $7: 3$ \\
C. $4: 3$ & \\
\hline
\end{tabular}
\end{tabular}

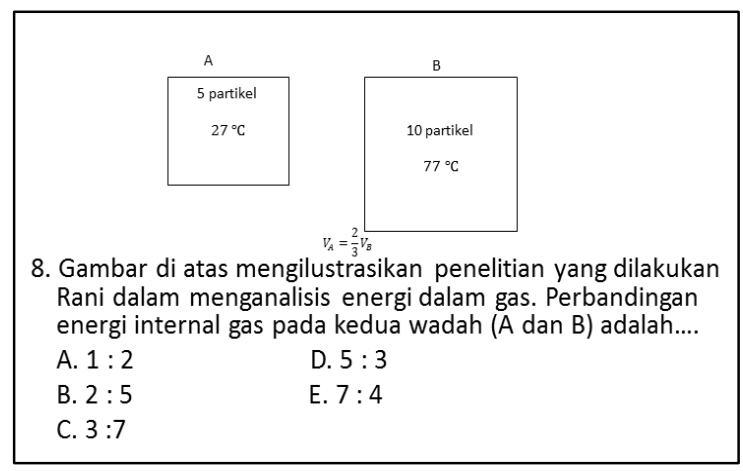

9. Zaldi melakukan percobaan fluida yang bertujuan
untuk mengetahui kelajuan efektif gas oksigen. Pada
suhu ruang, partikel gas oksigen bergerak dengan
kelajuan efektif $v$. Kemudian Zaldi memanaskan gas
tersebut hungga suhunya menjadi empat kali semula.
Kelajuan rata-rata gas setelah dipanaskan adalah....
$\begin{array}{ll}\text { A. } 1 / 2 v & \text { D. } 2 v \\ \text { B. } v & \text { E. } 4 v \\ \text { C. } \sqrt{2} 2 v & \end{array}$

Gambar 5 (a) Butir Soal No. 7, (b) Butir Soal No. 8, (c) Butir Soal No. 9

Soal terkait energi kinetik disajikan dengan memberikan grafik PV speerti gambar 5(a). Sebanyak 98,8\% siswa menjawab benar. Siswa memberikan alasan dengan rumusan bahwa energi kinetic sebanding dengan tekanan dan volume $(\bar{K}=$ $\left.\frac{3}{2} P V\right)$. Siswa menggunakan kesebandingan $\frac{\overline{\bar{K}_{D}}}{\bar{K}_{D}}=\frac{P_{C} V_{C}}{P_{D} V_{D}}$. Beberapa siswa juga menyatakan bahwa energi kinetik sebanding dengan suhu. Siswa menentukan suhu pada masing-maisng keadaan kemudian menentukan perbandingannya. Suhu pada kedua keadaan ditentukan dengan persamaan keadaan gas $T=\frac{P V}{n R}$ atau melalui kesebandingan $\frac{T_{C}}{T_{D}}=\frac{P_{C} V_{C}}{P_{D} V_{D}}$. Sementara itu, siswa yang menjawab salah menunjukkan kesalahannya pada perhitungan matematika.

Pemahaman siswa terhadap energi internal dilihat dari hasil jawaban soal pada gambar 5(b). Sebanyak 49,4\% siswa menjawab benar. Siswa memberikan alasan berupa rumusan energi internal $\left(U=\frac{3}{2} N k T\right)$ sehingga energi internal sebanding dengan jumlah partikel dan suhunya. Sebelumnya, siswa mengubah suhu gas ke dalam satuan internasional (K). Siswa menggunakan perbandingan matematika $\frac{U_{A}}{U_{B}}=\frac{N_{A} T_{A}}{N_{B} T_{B}}$. Kesalahan siswa terdapat pada hitungan matematika sehingga hasil akhir dari jawaban soal juga salah. Selain itu, miskonsepsi pada siswa menunjukkan bahwa energi internal bergantung pada volume gas. 
Pemahaman siswa tentang kelajuan rata-rata gas ideal, seperti pada gambar 5(c) juga masih rendah. Sebanyak 51,8\% siswa menjawab benar. Siswa memberikan alasan dengan menunjukkan rumusan kelajuan rata-rata gas ideal $\left(\bar{v}=\sqrt{\frac{3 k T}{m}}\right)$ sehingga kelajuan rata-rata sebanding dengan akar suhu gas $(\bar{v} \sim \sqrt{T})$. Siswa menggunakan perbandingan $\frac{\bar{v}_{1}}{\bar{v}_{2}}=\frac{\sqrt{T_{1}}}{\sqrt{T_{2}}}$. Siswa yang menjawab salah menunjukkan kesalahannya pada hitungan matematika. Selain itu, miskonsepsi terjadi pada hubugan kelajuan rata-rata dan suhu yang disebutkan saling berbanding terbalik.

\section{PEMBAHASAN}

Berdasarkan hasil penelitian, siswa telah menguasai konsep pada materi teori kinetik gas. Hal ini dibuktikan dengan nilai rata-rata siswa mencapai 7,1 dari skor maksimal 9. Siswa telah memahami persyaratan dalam menggunakan persamaan keadaan gas, hubungan antar variabel keadaan pada proses volume tetap, tekanan tetap, variabel keadaan yang berubah-ubah, dan energi kinetik gas ideal.

Penguasaan konsep merupakan suatu kemampuan dalam menganalisis fakta dan hubungannya dengan konsep yang ada. Lebih dari itu, penguasaan konsep juga menunjukkan pengungkapan makna dari ciri-ciri objek yang diamati (Kele \& Özsoy, 2009). Penguasaan konsep pada siswa ini dapat ditunjukkan dari cara siswa menggunakan konsep dalam berbagai jenis soal (Lin \& Singh, 2011). Hal ini dikarenakan siswa telah melewati pembelajaran yang baik sebelum tes sehingga dapat menjawab soal-soal penguasaan konsep dengan hasil yang baik. Pembelajaran memberikan banyak kontribusi dalam memberikan konsep yang benar kepada siswa (Başer, 2006; Korganci, Miron, Dafinei, \& Antohe, 2015; Sarıŏlan \& Küçüközer, 2014). Pada topik persyaratan gas ideal siswa telah mampu menyebutkan persyaratan tersebut. Namun, masih ada siswa yang mengalami miskonsepsi dengan menyebutkan bahwa partikel gas bergerak dengan percepatan tetap. Menurut konsep, partikel gas ideal tidak mengalami percepatan, hanya bergeser secara lurus dengan kecepatan yang konstan (Serway \& Jewett, 2008).

Konsep tentang hubungan antara tekanan dan volume pada proses suhu tetap $\left(P \sim \frac{1}{V}\right)$ di piston telah dipahami dengan baik. Namun, saat siswa dihadapkan dengan penerapan konsep tersebut pada menguasai konsep berhasil menyatakan bahwa tekana dalam serambi kanan mengecil saat keadaan mengembang (relaksasi). Miskonsepsi terjadi pada siswa yang menyatakan bahwa tekanan sebanding dengan volume (Talaeb, Wattanakasiwich, Paosawatyanyong, \& Wattanakasiwich, 2010). Hal ini menunjukkan bahwa siswa dapat menggunakan persamaan namun tidak dapat menghubungkan terhadap fenomena sehari-hari. Sejalan dengan itu, penelitian menyebutkan mahasiswa dengan tingkatan lebih tinggi juga tidak dapat menerapkan persamaan keadaan gas pada fenomena sehari-hari (Robertson \& Shaffer, 2016; Russ et al., 2009).

Konsep tentang hubungan antara tekanan dan suhu pada proses suhu tetap dan hubungan volume dan suhu pada proses tekanan tetap telah dikuasai oleh siswa. Siswa dapat menyebutkan secara matematis bahwa tekanan dan suhu berbanding lurus $(P \sim T)$ begitu pula dengan volume dan suhu $(V \sim T)$. Siswa juga menggunakan persamaan keadaan gas secara utuh dalam menentukan salah satu variabel keadaan gas $(P V=n R T)$ dalam proses tekanan, suhu, dan volume yang berubah-ubah. Namun, kesalahan yang dilakukan oleh siswa terkait hitungan matematika sehingga berpengaruh pada hasil akhir solusi dari soal. Dari hal ini terbukti bahwa salah satu kendala dalam penguasaan konsep fisika adalah lemahnya kemampuan matematika (Pollock et al., 2007).

Konsep tentang energi kinetik telah dikuasai oleh siswa. Siswa telah menyebutkan dengan benar bahwa energi kinetik sebanding dengan suhu gas $(\bar{K} \sim T)$. Namun, miskonsepsi terjadi saat siswa menentukan energi internal gas. Siswa hanya memperhatikan perubahan suhu akan mengubah energi internal gas. Siswa tidak memperhatikan bahwa jumlah partikel juga memengaruhi energi internal. Secara konsep, energi internal merupakan energi total yang dipengaruhi oleh jumlah partikel dan suhu $(U \sim N T)$ Hal ini sejalan dengan penelitian yang dilakukan pada guru yang tingkatannya lebih tinggi dari siswa yang menyatakan bahwa guru sulit menganalisis fenomena pada keadaan gas dengan jumlah partikel yang berubah (Sutopo, 2010). Dalam konsep ini, siswa juga mebgalami kesalahan pada hitungan matematis. Begitu pula dengan konsep kelajuan rata-rata gas ideal.

\section{SIMPULAN}

Berdasarkan hasil penelitian dan pembahasan, siswa telah menguasai konsep pada materi teori kinetik gas. Siswa telah menguasai konsep syarat-syarat gas ideal, hubungan antar varibel keadaan (persamaan keadaan gas), seperti hubungan tekanan dan suhu $(\mathrm{P} \sim \mathrm{T})$, suhu dan volume $(\mathrm{V} \sim \mathrm{T})$, dan energi kinetik. Siswa juga telah berhasil mengaitkan fakta seperti peristiwa pada tabung berpiston ketika digerakkan ke atas.

Konsep pada hubungan antara tekanan dan volume, energi internal, dan kelajuan rata-rata gas ideal masih mengalami beberapa kesulitan bagi siswa. Siswa masih mengalami kesulitan pada perhitungan matematis sehingga berpengaruh pada hasil akhir soal. Selain itu, siswa belum dapat mengaitkan fakta tentang kerja serambi kanan jantung saat mengembang dengan konsep hubungan antara tekanan dan volume pada proses suhu tetap sehingga menimbulkan miskonsepsi. Materi teori kinetik gas masih menimbulkan miskonsepsi di berbagai topik meskipun telah dipelajari oleh siswa. Dari kesulitan (miskonsepsi) ini dapat dikembangkan pembelajaran yang tepat untuk menanggulanginya. Selain itu, pembelajaran yang digunakan sebaiknya dapat membuat siswa aktif dalam pembelajaran agar siswa ikut serta dalam mengonstruk pemahaman konsep. 


\section{DAFTAR RUJUKAN}

Alwan, A. A. (2011). Misconception of Heat and Temperature Among Physics Students. Procedia - Social and Behavioral Sciences, 12, 600-614. https://doi.org/10.1016/j.sbspro.2011.02.074

Arikunto, S. (2010). Prosedur Penelitian Suatu Pendekatan Praktik (Revisi). Jakarta: Rineka Aksara.

Aydeniz, M., Pabuccu, A., Cetin, P. S., \& Kaya, E. (2012). Argumentation and Students' Conceptual Understanding of Properties and Behaviors of Gases. International Journal of Science and Mathematics Education, 10(6), 1303-1324. https://doi.org/10.1007/s10763-012-9336-1

Başer, M. (2006). Fostering Conceptual Change by Cognitive Conflict Based Instruction on Students' Understanding of Heat and Temperature Concepts. Eurasia Journal of Mathematics, Science and Technology Education, 2(2), 96-114. https://doi.org/10.12973/ejmste/75458

Bouwma-Gearhart, J., Stewart, J., \& Brown, K. (2009). Student Misapplication of a Gas-like Model to Explain Particle Movement in Heated Solids: Implications for Curriculum and Instruction Towards Students' Creation and Revision of Accurate Explanatory Models. International Journal of Science Education, 31(9), 1157-1174. https://doi.org/10.1080/09500690902736325

Chang, H., Chen, J., Guo, C., Chen, C., Chang, C., Lin, S., Tseng, Y. (2007). Investigating Primary and Secondary Students' Learning of Physics Concepts in Taiwan. International Journal of Science Education, 29(4), 465-482. https://doi.org/10.1080/09500690601073210

Cummings, K., Halliday, D., \& Activity Based Physics Group (Eds.). (2004). Understanding Physics. Hoboken, NJ: Wiley.

Ding, L., \& Beichner, R. (2009). Approaches to Data Analysis of Multiple-Choice Questions. Physical Review Special Topics Physics Education Research, 5(2), 020103. https://doi.org/10.1103/PhysRevSTPER.5.020103

Docktor, J. L., \& Mestre, J. P. (2014). Synthesis of Discipline-Based Education Research in Physics. Physical Review Special Topics - Physics Education Research, 10(2). https://doi.org/10.1103/PhysRevSTPER.10.020119

Duit, R. (2009, March 23). Bibliography - STCSE Students' and Teachers' Conceptions and Science Education. Retrieved April 12, 2019, From Bibliography - STCSE Students' and Teachers' Conceptions and Science Education Website: http://archiv.ipn.uni-kiel.de/stcse/stcse.html

Husnaini, S. J., \& Chen, S. (2019). Effects of Guided Inquiry Virtual and Physical Laboratories on Conceptual Understanding, Inquiry Performance, Scientific Inquiry Self-Efficacy, and Enjoyment. Physical Review Physics Education Research, 15(1), 010119. https://doi.org/10.1103/PhysRevPhysEducRes.15.010119

Jayanti, I. B. R., Wartono., \& Sutopo. (2016). Dampak Program Resitasi terhadap Perubahan Konseptual Mahasiswa pada Topik Hukum III Newton. Jurnal Pendidikan: Teori, Penelitian, dan Pengembangan, l(2), 256-264.

Kele, Ö., \& Özsoy, S. (2009). Pre-Service Teachers' Attitudes Toward use of Vee Diagrams in General Physics Laboratory. (3), 17.

Korganci, N., Miron, C., Dafinei, A., \& Antohe, S. (2015). The Importance of Inquiry-Based Learning on Electric Circuit Models for Conceptual Understanding. Procedia - Social and Behavioral Sciences, 191, 2463-2468. https://doi.org/10.1016/j.sbspro.2015.04.530

Lin, S.-Y., \& Singh, C. (2011). Using Isomorphic Problems to Learn Introductory Physics. Physical Review Special Topics Physics Education Research, 7(2), 020104. https://doi.org/10.1103/PhysRevSTPER.7.020104

Meltzer, D. E. (2004). Investigation of Students' Reasoning Regarding Heat, Work, and the First Law of Thermodynamics in an Introductory Calculus-Based General Physics Course. American Journal of Physics, 72(11), 1432-1446. https://doi.org/10.1119/1.1789161

Monteyne, K., Gonzalez, B., \& Loverude, M. (2008). An Interdisciplinary Study of Student Ability to Connect Particulate and Macroscopic Representations of a Gas. IP Conference Proceedings, 1064(1), 163-166.

Pollock, E. B., Thompson, J. R., Mountcastle, D. B., Hsu, L., Henderson, C., \& McCullough, L. (2007). Student Understanding of the Physics and Mathematics of Process Variables in P-V Diagrams. AIP Conference Proceedings, 168-171. https://doi.org/10.1063/1.2820924

Robertson, A. D., \& Shaffer, P. S. (2013). University Student and K-12 Teacher Reasoning about the Basic Tenets of KineticMolecular Theory, Part I: Volume of an Ideal Gas. American Journal of Physics, 81(4), 303-312. https://doi.org/10.1119/1.4775153

Robertson, A. D., \& Shaffer, P. S. (2016). University Student Reasoning about the Basic Tenets of Kinetic-Molecular Theory, Part II: Pressure of an Ideal Gas. American Journal of Physics, 84(10), 795-809. https://doi.org/10.1119/1.4960215

Russ, R. S., Coffey, J. E., Hammer, D., \& Hutchison, P. (2009). Making Classroom Assessment More Accountable to Scientific Reasoning: A Case for Attending to Mechanistic Thinking. Science Education, 93(5), 875-891. https://doi.org/10.1002/sce. 20320

Sands, D. (2014). Concepts and Conceptual Understanding: What Are We Talking About? New Directions, 10(1), 7-11. https://doi.org/10.11120/ndir.2014.00030

Sari, A. L. R., Parno., \& Taufiq, A. (2018). Pemahaman Konsep dan Kesulitan Siswa SMA pada Materi Hukum Newton. Jurnal Pendidikan: Teori, Penelitian, dan Pengembangan, 3(10), 1323-1330. 
Sarığlan, A. B., \& Küçüközer, H. (2014). The Effect of Meaning Making Instruction about Kepler's Laws at High School students' Conceptual Understanding. Procedia - Social and Behavioral Sciences, 143, 315-319. https://doi.org/10.1016/j.sbspro.2014.07.411

Serway, R. A., \& Jewett, J. W. (2008). Physics for Scientists and Engineers with Modern Physics. Belmont, CA: Thomson/Brooks/Cole.

Talaeb, P., Wattanakasiwich, P., Paosawatyanyong, B., \& Wattanakasiwich, P. (2010). Development of Thermodynamic Conceptual Evaluation. 183-186. https://doi.org/10.1063/1.3479864

Turgut, Ü., Gürbüz, F., \& Turgut, G. (2011). An Investigation $10^{\text {th }}$ Grade Students' Misconceptions about Electric Current. Procedia - Social and Behavioral Sciences, 15, 1965-1971. https://doi.org/10.1016/j.sbspro.2011.04.036 